\section{Rediscovery of Vosmer's Writhing Skink Lygosoma vosmaerii (Gray, 1839) (Reptilia: Scincidae) with a note on its taxonomy}

\section{Seetharamaraju ${ }^{1}$, R. Sreekar ${ }^{2}$, C. Srinivasulu ${ }^{3}$, Bhargavi Srinivasulu ${ }^{2}$, Harpreet Kaur ${ }^{1}$ \& P. Venkateshwarlu ${ }^{1}$}

1,3 Department of Zoology, University College of Science, Osmania University, Hyderabad, Andhra Pradesh 500007, India ${ }^{2}$ Biodiversity Research and Conservation Society, G4, MRK Towers, Swarnadhamanagar, Old Bowenpally, Secunderabad, Andhra Pradesh 500011, India

Email: ${ }^{3}$ hyd2masawa@gmail.com (corresponding author)

Among lizards, family Scincidae is the largest family comprising more than 1600 species (Bauer 1998) with four subfamilies, of which the subfamily Lygosominae is the largest with 600 species in 45 genera (Griffith et al. 2000). The writhing skinks belonging to the genus Lygosoma (Gray 1839) including about 38 species of which 15 species occur in the Oriental region (Bisby et al. 2009). Among these, 11 species of skinks belonging to Lygosoma Gray, 1839 are known from India (Sharma 2002). So far, four species of Lygosoma - L. punctata (Gmelin, 1799); L. albopunctata (Gray, 1846); L. guentheri (Peters, 1879) and L. ashwamedhi (Sharma, 1969) have been recorded from Andhra Pradesh (Smith 1935; Sharma 1969, 2002; Srinivasulu \& Das 2008; Javed et al. in review). In this paper a fifth species, L. vosmaerii (Gray, 1839), is added to the herpetofauna of Andhra Pradesh.

\section{Material and Methods}

We have been conducting herpetofaunal surveys in disturbed habitats of Andhra Pradesh to study the effects of

Date of publication (online): 26 December 2009

Date of publication (print): 26 December 2009

ISSN $0974-7907$ (online) | 0974-7893 (print)

Editor: Aaron Bauer

\section{Manuscript details:}

Ms \# 02160

Received 18 March 2009

Final received 16 November 2009

Finally accepted 24 November 2009

Citation: Seetharamaraju, M., R. Sreekar, C. Srinivasulu, Bhargavi Srinivasulu, Harpreet Kaur \& P. Venkateshwarlu (2009). Rediscovery of Vosmer's Writhing Skink Lygosoma vosmaerii (Gray, 1839) (Reptilia: Scincidae) with a note on its taxonomy. Journal of Threatened Taxa 1(12): 624-626.

Copyright: (C) M. Seetharamaraju, R. Sreekar, C. Srinivasulu, Bhargavi Srinivasulu, Harpreet Kaur \& P. Venkateshwarlu 2009. Creative Commons Attribution 3.0 Unported License. JoTT allows unrestricted use of this article in any medium for non-profit purposes, reproduction and distribution by providing adequate credit to the authors and the source of publication.

Acknowledgments: The authors are very much thankful to Sri Hitesh Malhotra IFS, Principal Chief Conservator of Forest (Wildlife) and Chief Wildlife Warden, Andhra Pradesh Forest Department, Hyderabad and Dr. V. B. Ramanamurthy, IFS, Member Secretary, Andhra Pradesh Biodiversity Board, Hyderabad for constant encouragement and sustained support for biodiversity research. We express gratitude to Prof. T. Tirupathi Rao, Vice Chancellor, Osmania University, Hyderabad and the Head, Department of Zoology, Osmania University, Hyderabad for encouragement and facilities.

OPEN AGGESS | FREE DOWNLOAD

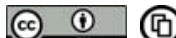

habitat conversion on herpetofaunal assemblages since June, 2007. During one such study in areas adjacent to limestone quarries in the Krishna district of Andhra Pradesh, on 11 January, 2009, an adult specimen of lined supple skink was collected from the vicinity of Jaggayyapet $\left(16^{\circ} 52^{\prime} \mathrm{N} \& 80^{\circ} \mathrm{O} 5^{\prime} \mathrm{E}\right)$. The collected specimen (NHM.OU.REP.1-2009; Image 1) is preserved in $70 \%$ alcohol and deposited in the Natural History Museum, Osmania University, Hyderabad, Andhra Pradesh, India. Careful observation of the specimen revealed it to be Vosmer's Writhing Skink Lygosoma vosmaerii (Gray, 1839). The morphometric measurements were taken using digital calipers and are given to the nearest $0.1 \mathrm{~mm}$.

Results

Diagnosis: The body of Lygosoma vosmaerii (Gray, 1839) is slender, much elongated with distinct 16 longitudinal lines on its dorsum (Image 1). Colour of the body is golden brown dorsally. The limbs are dark brownish above and paler below. The longitudinal lines are formed by the dark brown spots on the scales that are darker and prominent on the dorsum and faded on the venter. The four middle longitudinal lines form a spear-shaped marking anteriorly (Image 2), starting just behind the snout and continuing to the middle of the tail, which is red in colour (Image 1).

Snout obtusely pointed, supranasals entire, just touching one another behind the rostral; frontal smaller than the single large shield-like fronto-parietal. Lower eyelid with an undivided semitransparent disc. Seven upper labials, of which the fourth and fifth touch the eye. Ear opening is small and not covered by scales. Parietals touch each other behind the interparietal. Nuchals absent. Limbs very short with five fingers (Images $3 \& 4$ ) and four toes; the third toe being the largest. Digits with smooth subdigital lamellae. Preanals not enlarged. The morphometric and mersitic data of the specimen is provided in Table 1 .

Habits and habitat: The habitat where the specimen was found is dry scrub forest interspersed with grass patches, termite mounds, ant hills and boulders. These conditions provide ample amounts of food source in the form of termites, ants and insects like grass-hoppers, stick-insects, etc. The specimen was found under a boulder. The surface of the soil under the rock had many cracks that allowed free movement and provided protection.

\section{Discussion \& Conclusions}

Lygosoma vosmaerii (Gray, 1839) can be distinguished from L. lineata (Gray, 1839) by its five fingers instead of four (Gray 1839; Boulenger 1890; Smith 1935; Vyas 2001). The Vosmer's

Abbreviations: Measurements and morphometry: TBL - Total body length; SVL - Snout to vent length; TL - Tail length (from cloaca to tail tip); A-G - Axilla to groin distance; HL - Distance between angle of jaw and snout tip; DFL-ST - Distance from forelimb to snout tip; IN Distance between nostrils; E-N - Eye to nostril distance; E-S - Eye to snout-tip distance; E-E - Ear opening to eye distance; ED - Greatest eye diameter; EL - Greatest length of ear opening; HW - Head width at angle of jaw; IO - Minimum distance between upper eyelids; FLL Forelimb length; HLL - Hindlimb length; DO-SR - Dorsal scale rows (between nuchal and hind limb); BE-SR - Ventral scale rows (between fore and hind limbs). 

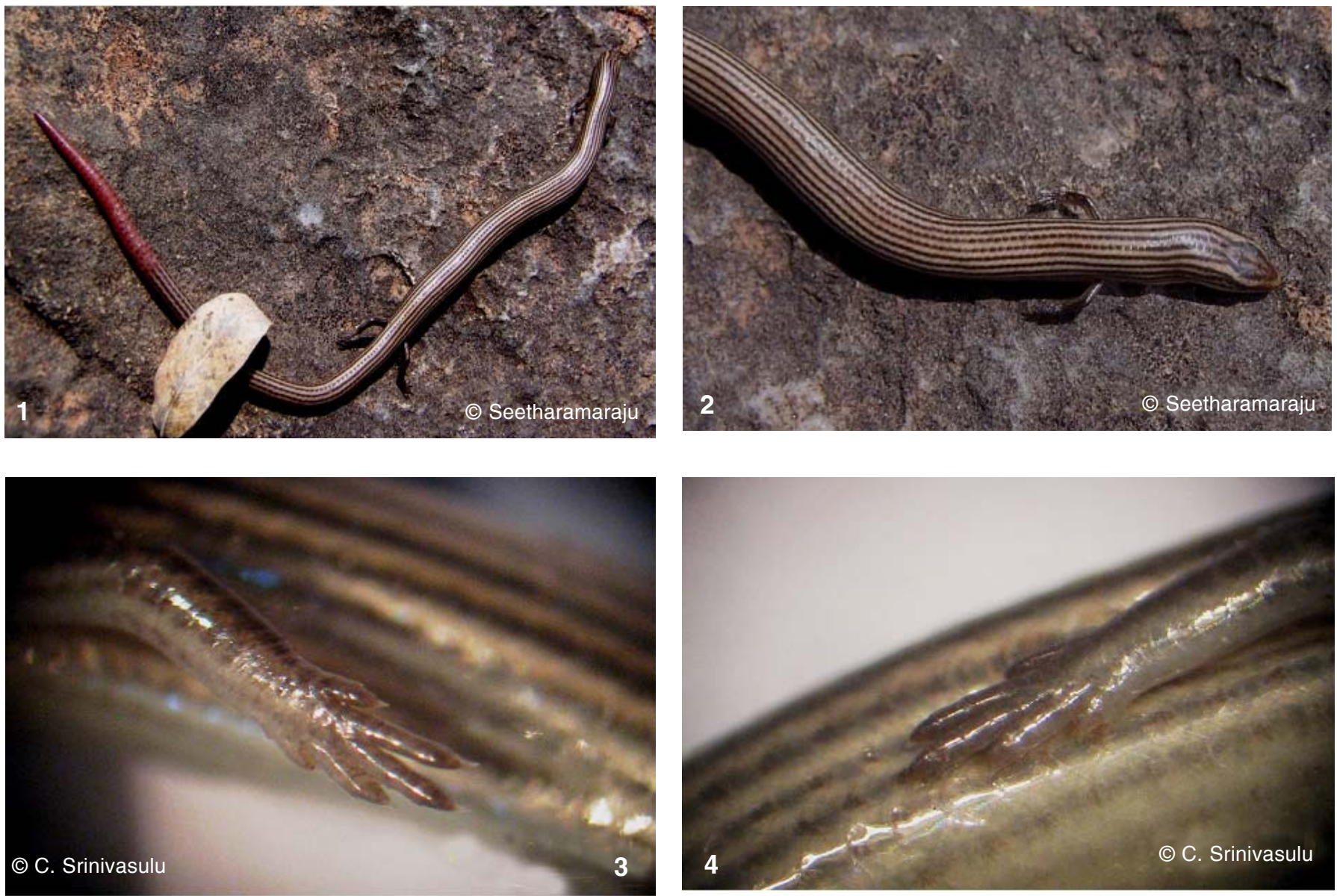

Images 1-4. 1 - Lygosoma vosmaerii (Gray, 1839) (live) entire; 2 - Close up of the head and trunk detailing dorsal marking pattern; 3 - Close up of the left forelimb showing five fingers; 4 - Close up of the right forelimb showing five fingers

Writhing Skink L. vosmaerii was described as Hagria vosmaerii by Gray (1839), as is presently accepted, with Java as its type locality based on a specimen sent to him by Gabriel Bibron (Gray 1845). Duméril \& Bibron (1839) provided a full description of the same specimen which was collected by $\mathrm{M}$. Lamarre-Piquot from Bengal Province as Campsodactylus lamarrei (as a new species). This later publication (Duméril \& Bibron 1839) clarifies the fact that Gray (1839) has misquoted the type locality and correctly assigns the same from Indian region. Later, Boulenger (1887) allocated it to the genus Lygosoma and assigned 'Bengal' as its locality. Boulenger (1890) considered the holotype (MNHN 777; ex-MNHN 3007; fide Brygoo 1985) of L. vosmaerii (Gray 1839) to be an apparently anomalous specimen of L. lineata (Gray, 1839), although Smith (1935) and Sharma (2002) treated both the taxa as distinct. The synonymy of $L$. vosmaerii (Gray, 1839) includes the following nomen - Hagria vosmaerii Gray, 1839, Riopa vosmaerii (Gray, 1839) and Campsodactylus lamarrei Duméril \& Bibron, 1839 (Bisby et al. 2009; Uetz 2009).

Prior to the rediscovery of L. vosmaerii (Gray, 1839) in eastern peninsular India from Jaggayapet, Krishna District, Andhra Pradesh, this taxon was seldom included in literature (see Das 2003). Recently, Vyas (2001) noted that one specimen of L. lineata (Gray, 1839) from Gujarat had five fingers on right hand and in agreement to Boulenger (1890) treated $L$. vosmaerii (Gray, 1839) as anomalous specimen of L. lineata (Gray, 1839) and proposed the synonymy of the former with the latter. The recent rediscovery clarifies the taxonomic status of L. vosmaerii (Gray, 1839) and future surveys in the Eastern Ghats and forests between the Godavari river basin and the Satpura-Maikal Hills might throw further light on the distribution and biology of Vosmer's Writhing Skink.

\section{References}

Bauer, A.M. (1998). Lizards. pp. 126-173. In: Cogger, H.G. \& R.G. Zweifel (eds.). Reptiles and Amphibians $2^{\text {nd }}$ edition. Academic Press, San Diego.

Bisby F.A., Y.R. Roskov, T.M. Orrell, D. Nicolson, L.E. Paglinawan, N. Bailly, P.M. Kirk, T. Bourgoin, \& G. Baillargeon (eds.) (2009). Species 2000 \& ITIS Catalogue of Life: 2009 Annual Checklist. CD-ROM; Species 2000. Reading, UK.

Boulenger, G.A. (1887). Catalogue of the Lizards in the British Museum (Nat. Hist.) III. Lacertidae, Gerrhosauridae, Scincidae, Anelytropsidae, Dibamidae, Chamaeleontidae. Taylor and Francis, London, 575pp.

Boulenger, G.A. (1890). The Fauna of British India, including Ceylon and Burma. Reptilia and Batrachia. Taylor and Francis, London. xviii + $541 \mathrm{pp}$.

Brygoo, É.R. (1985). Les types de Scincidés (Reptiles, Sauriens) du Muséum national d'Histoire naturelle. Catalogue critique. Bulletin du Museum National d'Historie Naturelle. 4 E serie. Section A. Zoologie, Biologie et Ecologie animales (3)suppl.: 1-126.

Das, I. (2003). Growth of knowledge on the reptiles of India, with an introduction to systematics, Taxonomy and Nomenclature. Journal of the Bombay Natural History Society 100(2 \& 3): 446-501.

Duméril, A.M.C. \& G. Bibron (1839). Erpétologie générale ou histoirie naturelle complète des reptiles. vol. 5. Roret/Fain et Thunot, Paris, $871 \mathrm{pp}$.

Gray, G.R. (1845). Reptiles. Pp 1-8. In: Richardson, J. \& J.E. Gray (eds.) 
Table 1. Morphometric and mersitic data on Lygosoma vosmaerii (Gray, 1839) (NHM.OU.REP.1-2009) from Jaggayapet, Krishna District, Andhra Pradesh (All morphometric measurements in $\mathrm{mm}$ )

\begin{tabular}{|c|c|}
\hline Character & NHM.OU.REP.1 (Female) \\
\hline \multicolumn{2}{|c|}{ Morphometric } \\
\hline TBL & 121.6 \\
\hline SVL & 57.0 \\
\hline $\mathrm{TL}$ & 64.6 \\
\hline$A-G$ & 42.9 \\
\hline $\mathrm{HL}$ & 3.5 \\
\hline DFL-ST & 10.7 \\
\hline IN & 0.85 \\
\hline E-N & 1.3 \\
\hline E-S & 1.7 \\
\hline$E-E$ & 2.7 \\
\hline ED & 1.2 \\
\hline EL & 0.55 \\
\hline HW & 3.2 \\
\hline 10 & 0.5 \\
\hline FLL & 4.78 \\
\hline HLL & 8.25 \\
\hline \multicolumn{2}{|c|}{ Meristic } \\
\hline DO-SR & 22 \\
\hline BE-SR & 90 \\
\hline \multicolumn{2}{|c|}{ Lamellae (divided; Fingers $1-5$, Toes $1-4$ ) } \\
\hline Fingers Right side & $3: 6: 6: 4: 2$ \\
\hline Fingers Left side & $3: 7: 7: 4: 2$ \\
\hline Toes Right side & $2: 5: 8: 8$ \\
\hline Toes Left side & $3: 7: 8: 9$ \\
\hline \multicolumn{2}{|c|}{ Labials (Right side / Left side) } \\
\hline Supralabials & $7 / 7$ (4,5 touch eye) \\
\hline Infralabials & $6 / 6$ \\
\hline
\end{tabular}

The Zoology of the voyage of H.M.S. Erebus \& Terror: under the command of Captain Sir James Clark Ross, during the years 1839 to 1843. Vol. IV. Reptiles, Fishes, Crustacea, Insects and Mollusca. E.W. Janson, London. $221 \mathrm{pp}$.

Gray, J.E. (1839). Catalogue of the slender- tongued saurians, with descriptions of many new genera and species. Annals and Magazine of Natural History 2: 331-337.

Griffith, H., A. Ngo \& R.W. Murphy (2000). A cladistic evaluation of the cosmopolitan genus Eumeces Wiegmann (Reptilia, Squamata, Scincidae). Russian Journal of Herpetology 7(1): 1-16.

Javed, S.M.M., Seetharamaraju, K. Thulsi Rao, Farida Tampal and C. Srinivasulu (in review). Distribution and Status of Lygosoma guentheri (Peters, 1879) (Reptilia: Scincidae) in Andhra Pradesh, India. Submitted to Journal of Threatened Taxa.

Sharma, R.C. (1969). Two new lizards of the genera Mabuya Fitzinger and Riopa Gray (Scincidae) from India. Bulletin of Systematic Zoology, Calcutta 1(2):71-75.

Sharma, R.C. (2002). The Fauna of India and the Adjacent Countries. Reptilia. Volume II, Sauria. Zoological Survey of India, Kolkata, xxv+430pp.

Smith, M.A. (1935). The Fauna of British India, including Ceylon and Burma. Reptilia and Amphibia. Vol. II.- Sauria. Taylor and Francis, London, xiii+440pp.

Srinivasulu, C. \& I. Das (2008). The Herpetofauna of Nallamala Hills, Eastern Ghats, India: An Annotated Checklist, With Remarks on Nomenclature, Taxonomy, Habitat Use, Adaptive Types and Biogeography. Asiatic Herpetological Research 11: 110-131.

Uetz, P. (2009). The TIGR Reptile Database. Online Database at http:/ /www.reptile-database.org. Accessed on 16 November 2009.

Vyas, R. (2001). Notes on the distribution of Lygosoma lineata (Gray, 1839 ) and comments on the systematic status of Lygosoma vosmaerii (Gray, 1839). Hamadryad 26(2): 360-361. 